\title{
PENERAPAN PEMBELAJARAN SIKLUS BELAJAR 7 FASE DALAM PENINGKATAN HASIL BELAJAR IPA MATERI LISTRIK DINAMIS KELAS IXB SMPN 1 POGALAN
}

\author{
JAINI \\ SMP Negeri 1 Pogalan, Trenggalek, Jawa Timur \\ e-mail: jainizen1503@gmail.com
}

\begin{abstract}
ABSTRAK
Penelitian ini dilatarbelakangi oleh rendahnya prestasi belajar siswa. Selama ini model pembelajaran yang sering diterapkan untuk meningkatkan keterampilan proses dan prestasi belajar belajar IPA siswa kelas IXB SMPN 1 Pogalan adalah direct intruction. Namun model tersebut belum bisa meningkatkan keterampilan proses dan prestasi belajar belajar secara optimal sesuai dengan kriteria ketuntasan minimal (KKM) dan ketuntasan klasikal. Dari prestasi belajar ulangan harian materi listrik statis diperoleh prestasi belajar siswa yang mencapai KKM hanya 5 orang. Ini berarti ketuntasan klasikal baru mencapai $25 \%$. Penelitian ini bertujuan untuk mengetahui peningkatkan prestasi belajar IPA materi listrik dinamis melalui model siklus belajar 7 fase (The 7e Learning Cycle Model) Pada Siswa Kelas IXB Tahun Pelajaran 2019/2020 di SMPN 1 Pogalan Hasil penelitian menunjukkan bahwa pembelajaran siklus belajar 7 fase dapat meningkatkan prestasi belajar belajar siswa kelas IXB SMPN 1 Pogalan. Peningkatan jumlah siswa yang tuntas belajar dari siklus I ke siklus II yaitu pada siklus I siswa yang tuntas belajar sebanyak 18 siswa (62\%) dan pada siklus II sebanyak 26 siswa (90\%). Rata-rata nilai prestasi belajar belajar kognitif siswa mengalami peningkatan $30 \%$ yaitu dari 70,5 pada siklus I menjadi 80,5 pada siklus II. Berdasakan kesimpulan, peneliti merekomendasikan agar guru mata pelajaran menerapkan model pembelajaran tersebut pada materi dengan karakteristik yang sesuai, sedangkan untuk peneliti lain yang ingin menggunakan model pembelajaran yang sama hendaknya juga meneliti aspek lain selain aspek kognitif pada prestasi belajar belajar siswa yaitu aspek afektif dan aspek psikomotor, di samping itu guru harus menggunakan waktu seefektif dan seefisien mungkin agar cukup untuk menyampaikan materi sesuai dengan target kurikulum.
\end{abstract}

Kata kunci: pembelajaran siklus belajar 7 fase, prestasi belajar

\section{PENDAHULUAN}

Pembelajaran IPA di SMP/MTs menekankan pemberian pengalaman belajar secara langsung. Kata lainnya metode pembelajaran dengan teacher centered harus diubah menjadi student centered. Tujuannya agar siswa mampu berpikir kritis dan kreatif serta lebih peka menghadapi masalah yang terjadi dalam kehidupan sehari-hari. Dewey (dalam Toharudin (2005:54)) menyatakan bahwa sekolah semestinya harus mampu mengajarkan siswa berpikir. Pernyataan Dewey sangat relevan dengan standar isi pada KTSP karena pembelajaran IPA diarahkan agar dapat diterapkan secara inkuiri ilmiah (scientific inquiry). Tujuannya agar siswa mampu berpikir, bekerja, dan bersikap serta mengkomunikasikannya sebagai aspek penting kecakapan hidup (life skill). Standar isi memuat keharusan bagi guru untuk mampu menyusun silabus serta rencana pelaksanaan pembelajaran (RPP) secara mandiri yang disesuaikan dengan keadaan pada tiap-tiap sekolah. Hal ini menunjukkan bahwa sekolah harus mampu menjadikan lingkungannya sebagai media pembelajaran yang efektif bagi siswa.

Model pembelajaran IPA saat ini dikembangkan dari teori belajar konstruktivisme (constructivism teory). Pembelajaran dengan pendekatan konstruktivisme merupakan pendekatan pembelajaran yang memberikan pengakuan terhadap keragaman siswa. Pandangan pembelajaran konstruktivisme mengakui bahwa siswa pada awal proses pembelajaran telah memiliki konsep kognitif, afektif, dan psikomotorik tertentu sebagai akibat pembelajaran dan pengalaman sebelumnya. Bertolak dari pengetahuan awal dan pengalamannya ini siswa 
membangun sendiri pandangan mereka terhadap pengetahuan baru yang sedang diperolehnya (Wuryadi, (2000:3)).

Proses pembelajaran dengan pendekatan konstruktivisme, siswa dibantu untuk menginternalisasi, membentuk atau mentrasformasi pengetahuan yang baru. Transformasi terjadi melalui adanya pemahaman baru sebagai hasil munculnya struktur kognitif yang baru. Tugas guru dalam pembelajaran konstruktivisme adalah memfasilitasi siswa untuk memperoleh dan mengingat pengetahuan dengan cara antara lain: (a) menjadikan pengetahuan bermakna dan relevan bagi siswa, (b) memberi kesempatan kepada siswa untuk menemukan dan menerapkan idenya sendiri, (c) menyadarkan siswa agar menerapkan strategi sendiri dalam belajar (Nurhadi, dkk. (2004:13)).

Model pembelajaran yang sering diterapkan untuk meningkatkan keterampilan proses dan prestasi belajar IPA siswa kelas IXB SMPN 1 Pogalan, yaitu direct intruction. Namun model tersebut belum bisa meningkatkan keterampilan proses dan prestasi belajar secara optimal sesuai dengan kriteria ketuntasan minimal (KKM) dan ketuntasan klasikal. KKM di SMPN 1 Pogalan untuk bidang studi IPA ditetapkan sebesar 75 dan ketuntasan klasikal 85\%. Dari hasil ulangan harian materi listrik statis diperoleh hasil siswa yang mencapai KKM hanya 5 orang. Ini berarti ketuntasan klasikal baru mencapai $25 \%$.

Sudrajad (2010:3) menyatakan model pembelajaran direct instruction memiliki beberapa kelemahan yaitu: (1) guru sulit untuk mengatasi perbedaan dalam hal kemampuan, pengetahuan awal, tingkat pembelajaran dan pemahaman, gaya belajar, atau ketertarikan siswa, (2) karena siswa hanya memiliki sedikit kesempatan untuk terlibat secara aktif, sulit bagi siswa untuk mengembangkan keterampilan sosial dan interpersonal mereka, (3) tingkat struktur dan kendali guru yang tinggi dalam kegiatan pembelajaran, yang menjadi karakteristik model pembelajaran direct instruction, dapat berdampak negatif terhadap kemampuan penyelesaian masalah, kemandirian, dan keingintahuan siswa, (4) jika materi yang disampaikan bersifat kompleks, rinci, atau abstrak, model pembelajaran langsung tidak dapat memberi kesempatan yang cukup pada siswa untuk memproses dan memahami informasi yang disampaikan, (5) model pembelajaran langsung tidak banyak melibatkan siswa, siswa akan kehilangan perhatian setelah 10 -15 menit dan hanya akan mengingat sedikit isi materi yang disampaikan, (6) karena model pembelajaran langsung melibatkan banyak komunikasi satu arah, guru sulit untuk mendapatkan umpan balik mengenai pemahaman siswa.

Berdasarkan pengalaman mengajar materi listrik dinamis di kelas IX-A pada semester 1 tahun pelajaran 2019/2020 di SMP Negeri 1 Pogalan dengan model pembelajaran direct intruction dan metode ceramah diperoleh temuan bahwa siswa umumnya merasa kesulitan untuk memahami konsep listrik dinamis. Guru mendominasi proses pembelajaran dan lebih menekankan pada penyampaian produk IPA (konsep, teori dan hukum) dan kurang memperhatikan keterampilan proses IPA. Siswa cenderung pasif dalam proses pembelajaran. Akibatnya hasil ulangan harian siswa rendah, dari 20 siswa yang mendapat nilai 75 ke atas sebanyak 10 orang. Ini berarti ketuntasan klasikal baru mencapai 50\%, dan secara klasikal belum tuntas. Demikian juga keterampilan proses IPA yang dicapai siswa rendah, ditandai antara lain siswa kurang terampil menggunakan alat-alat praktikum, siswa kurang berani mengajukan pertanyaan dan mengemukakan pendapat.

Hal yang diperlukan untuk mengatasi permasalahan tersebut adalah model pembelajaran yang berpusat pada siswa (student centered) sehingga terbentuk interaksi multi arah yaitu pola interaksi guru dan siswa, siswa dan siswa. Hal ini dimaksudkan agar tidak menimbulkan kebosanan, kejenuhan, serta untuk menghidupkan suasana kelas, sehingga keterampilan proses, dan prestasi belajar siswa meningkat.

Obyek penelitian ini adalah kelas IXB SMPN 1 Pogalan tahun pelajaran 2019/2020 yang berjumlah 29 siswa terdiri dari 14 siswa laki-laki dan 25 siswa perempuan. Model pembelajaran yang berpusat pada siswa, salah satunya adalah siklus belajar 7 fase (The $7 E$ Learning Cycle Model). Pembelajaran siklus belajar 7 fase siklus belajar dalam pembelajaran ini terdiri dari 
tujuh tahapan yaitu tahap engage, tahap elicite, tahap explore, tahap explain, tahap elaborate, tahap evaluate, dan tahap extend.

Beberapa penelitian menunjukkan bahwa penerapan pembelajaran dengan model siklus belajar dapat meningkatkan keterampilan proses dan prestasi belajar siswa di tingkat SD, SMP, maupun siswa SMA. Semakin banyak keterlibatan aktif siswa dalam pembelajaran semakin tinggi pula prestasi belajar kognitifnya. Melalui kegiatan pembelajaran dengan siklus belajar, siswa terkondisi untuk mengkonstruksi informasi sendiri. Kemampuan mengkonstruk informasi sendiri sesuai dengan paradigma pembelajaran konstruktivisme (Nuryani, (2005:3)).

Eisenkraft (2003:56-59) menyatakan bahwa kelebihan siklus belajar 7 fase antara lain: merangsang siswa untuk mengingat kembali materi pelajaran yang telah mereka dapatkan sebelumnya, memberikan motivasi kepada siswa untuk menjadi lebih aktif dan menambah rasa keingintahuan, melatih siswa belajar menemukan konsep melalui kegiatan eksperimen, melatih siswa untuk menyampaikan secara lisan konsep yang telah mereka pelajari, memberikan kesempatan kepada siswa untuk berpikir, mencari, menemukan, dan menjelaskan contoh penerapan konsep yang telah dipelajari.

\section{METODE PENELITIAN}

Jenis penelitian yang dilakukan adalah penelitian tindakan kelas. Desain penelitian yang digunakan mengacu pada model Kemmis dan M.C Taggart (dalam Susilo, (2008: 2)) yang terdiri dari empat komponen, yaitu: perencanaan tindakan, pelaksanaan tindakan, observasi dan refleksi. Diagram alur desain penelitian ditunjukkan pada Gambar 1.

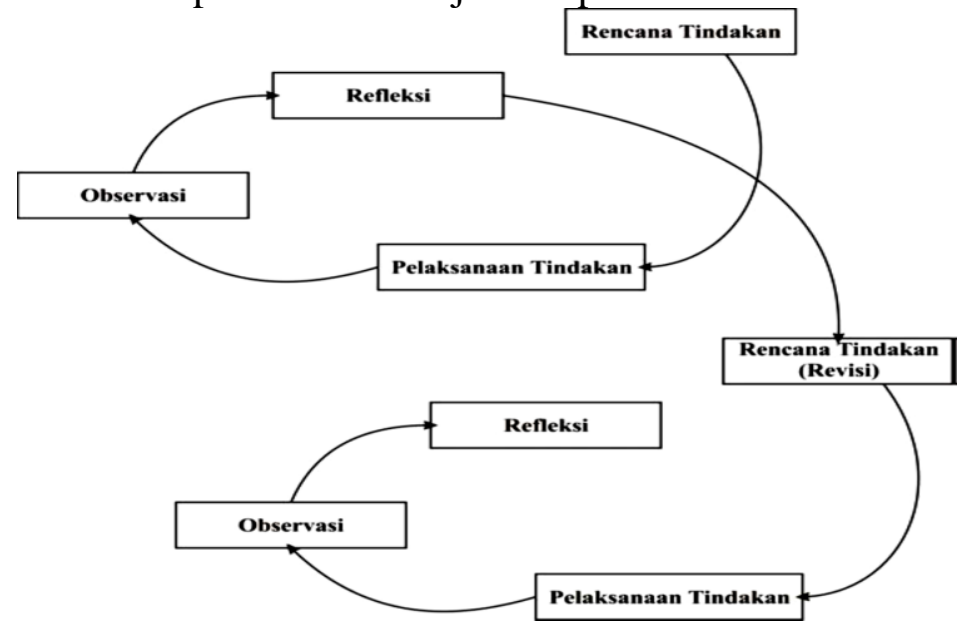

\section{Gambar 1 Diagram Alur Desain Penelitian Tindakan Kelas}

Penelitian dilakukan dalam 2 siklus, tiap siklus terdiri dari 4 kali pertemuan. Instrumen yang digunakan berupa perangkat pembelajaran, lembar kerja siswa, catatan lapangan dan soal tes tertulis. Sedangkan teknik pengumpulan data dilakukan dengan pengamatan langsung (observasi), tes tertulis berupa post test pada akhir tiap siklus. Data catatan lapangan diperoleh dari hasil pengamatan maupun rekaman aktivitas guru dan siswa yang tidak terekam dalam lembar observasi. Observasi dilakukan peneliti berkolaborasi dengan guru sejawat. Sedangkan data hasil test yang telah terkumpul dianalisis dengan mengkonsultasikan dengan ketuntasan mata pelajaran (KKM).

\section{HASIL DAN PEMBAHASAN}

\section{Hasil}

Data hasil tes kognitif siklus I yang dilaksanakan menggunakan soal Pos Tes I disajikan dalam tabel 1. 
Vol 1. No 2. Oktober Tahun 2021 e-ISSN : 2798-5466 P-ISSN : 2798-5725

\begin{tabular}{|c|c|c|c|}
\hline Rentang nilai & Banyak Responden & Kategori & $\begin{array}{c}\text { Persentase } \\
\text { Ketuntasan }\end{array}$ \\
\hline $91-100$ & 4 & \multirow{2}{*}{ Tuntas } & $62 \%$ \\
\hline $81-90$ & 3 & & \\
\hline $71-80$ & 11 & \multirow{2}{*}{ Tidak Tuntas } & $38 \%$ \\
\hline $61-70$ & 4 & & \\
\hline $51-60$ & 7 & \multicolumn{2}{|c}{} \\
\hline
\end{tabular}

Berdasarkan Tabel 1. dapat diketahui bahwa siswa yang telah mencapai KKM 18 orang dengan persentase $62 \%$, rata-rata nilai ketercapaian kemampuan kognitif pada siklus I sebesar 70,5. Siswa yang belum tuntas 11 orang dengan persentase $38 \%$. Secara klasikal ketuntasan sebesar $60 \%$ belum memenuhi syarat ketuntasan klasikal yang ditentukan yaitu $85 \%$.

Tindakan yang dirancang pada tahap ini masih menggunakan pembelajaran siklus belajar 7 fase. Siklus II juga terdiri dari empat kali pertemuan. Pokok bahasan pada siklus II adalah listrik dinamis dengan sub pokok bahasan rangkaian hambatan, pada pertemuan ke $\mathrm{V}$ dan VI. Pertemuan ke VII sumber arus listrik searah, pertemuan ke VIII gaya gerak listrik dan tegangan jepit Pada perencanaan tindakan siklus II ini, dilakukan penyusunan perangkat pembelajaran yaitu RPP dan LKS.

Berdasarkan pada kekurangan yang ada pada siklus I, maka pada siklus II dilakukan perbaikan. Upaya perbaikan-perbaikan yang dilakukan pada siklus II berdasarkan kekurangan pada siklus I adalah sebagai berikut. (a) pada pelaksanaan pembelajaran siklus II, guru lebih memperhatikan alokasi waktu sehingga semua tahapan pembelajaran dapat terlaksana dengan baik, (b). guru memberikan kesempatan yang seluas-luasnya kepada siswa untuk melakukan percobaan dengan caranya sendiri, (c). dilakukan perubahan anggota kelompok.

Data hasil tes kognitif siklus II yang dilaksanakan menggunakan soal Pos Tes 2 disajikan dalam tabel 2.

Tabel 2. Prestasi Belajar Kognitif Siklus II

\begin{tabular}{|c|c|c|c|}
\hline Rentang nilai & Banyak Responden & Kategori & $\begin{array}{c}\text { Persentase } \\
\text { Ketuntasan }\end{array}$ \\
\hline $91-100$ & 7 & \multirow{2}{*}{ Tuntas } & $90 \%$ \\
\hline $81-90$ & 6 & & \\
\hline $71-80$ & 13 & \multirow{2}{*}{ Tidak Tuntas } & $10 \%$ \\
\hline $51-70$ & 3 & & \\
\hline $51-60$ & 0 & &
\end{tabular}

Dari Tabel 2. dapat diketahui siswa yang mencapai KKM 26 siswa dengan persentase $90 \%$ dan yang belum tuntas 3 orang dengan persentase $10 \%$. Rata-rata nilai ketercapaian kemampuan kognitif pada siklus II sebesar 80,50. Ketuntasan klasikal siklus II sebesar 90\% sudah lebih besar dari ketuntasan klasikal yang ditetapkan sebesar $85 \%$. Terjadi peningkatan dari siklus I sebesar $28 \%$.

Dari hasil observasi selama dua siklus yaitu siklus I dan siklus II diperoleh data prestasi belajar siswa yang meliputi aspek aspek kognitif. Untuk lebih jelasnya disajikan pada Gambar 2 . 


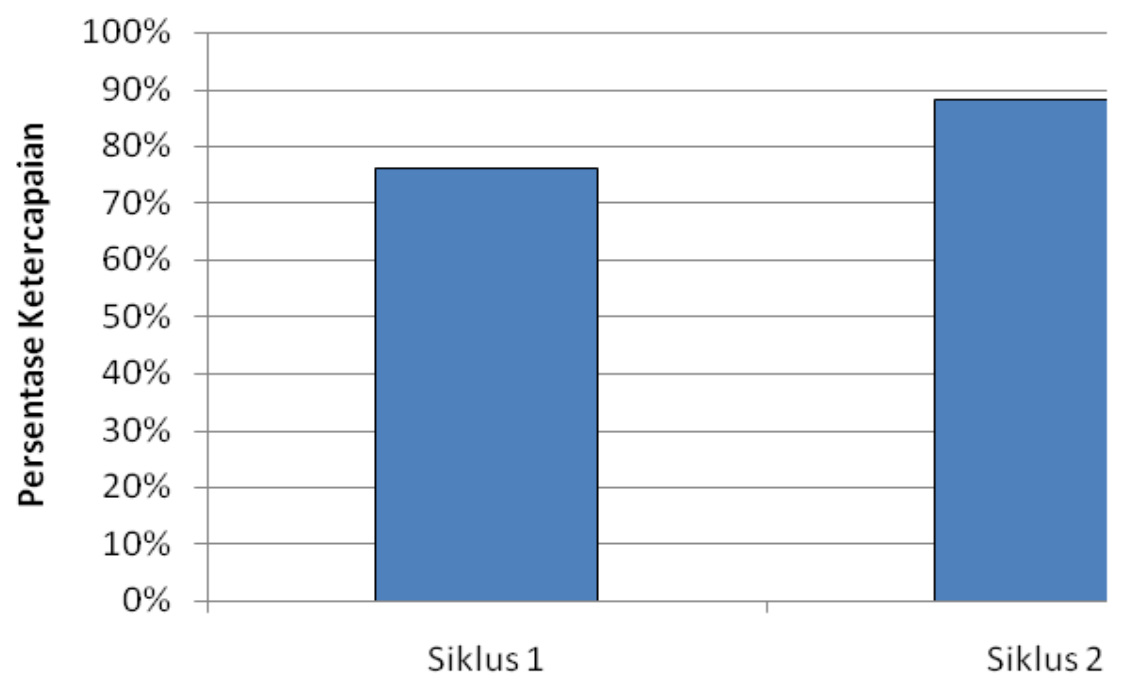

Gambar 2. Ketercapaian Kemampuan Aspek Kognitif Siswa

Keterlaksanaan pembelajaran siklus belajar mengalami peningkatan dari siklus I ke siklus II. Prestasi belajar siswa juga mengalami peningkatan. Untuk itu pembelajaran tidak dilanjutkan ke siklus III. Aspek kognitif mengalami peningkatan yang ditandai dengan peningkatan ketuntasan klasikal sebesar $76 \%$ pada siklus I menjadi $88 \%$ pada siklus II.

\section{Pembahasan}

Berdasarkan observasi dan refleksi menunjukkan bahwa pembelajaran model siklus belajar 7 fase dapat meningkatkan prestasi belajar kognitif siswa. Observasi dan refleksi siklus I menunjukkan bahwa 18 siswa (62\%) tuntas belajar, sedangkan 11 siswa (38\%) masih belum tuntas belajar. Apabila dilihat dari ketuntasan belajar secara klasikal, dapat dikatakan bahwa kelas IXB belum tuntas belajar, karena siswa di kelas IXB yang telah tuntas belajar sebanyak $62 \%$ atau kurang dari $85 \%$ siswanya tuntas belajar. Skor tes rata-rata yang telah dicapai oleh kelas IXB pada siklus I adalah 70,5.

Prestasi belajar kognitif siswa dapat ditingkatkan dengan pembelajaran siklus belajar 7 fase karena pembelajaran ini dapat melibatkan siswa dalam kegiatan belajar aktif mulai dari merencanakan penyelidikan, melaksanakan penyelidikan, dan mengkomunikasikan hasi penyelidikan serta bersikap ilmiah. Dasna (2004:39) menyatakan bahwa fase-fase pada pembelajaran siklus belajar merupakan kegiatan yang sangat penting dalam pengembangan konsep yang dipelajari. Menurut Winkle (1996: 244) cara belajar dengan menemukan sendiri sesuai dengan hakikat manusia sebagai seorang yang mencari-cari secara aktif dan menghasilkan pengetahuan dan pemahaman yang sungguh-sungguh bermakna. Kelebihan dari cara belajar ini ialah hasilnya lebih berakar dan mengendap dari pada cara belajar yang lain.

Penerapan pembelajaran dengan model siklus belajar 7 fase membantu siswa belajar melalui keaktifan untuk membangun pengetahuannya sendiri sehingga pada struktur kognitif siswa terjadi proses membandingkan informasi baru dengan pemahaman yang telah dimiliki, dan menggunakan semua pengetahuan atau pengalaman itu untuk bekerja melalui perbedaanperbedaan yang ada pada pengetahuan baru dan lama untuk mencapai pemahaman baru. Melalui pembelajaran siklus belajar 7 fase siswa belajar IPA dengan mengkonstruk sendiri pengetahuan melalui interaksi langsung dengan objek yang dipelajari. Adanya interaksi langsung siswa dengan objek yang dipelajari menyebabkan pengetahuan dan pemahaman yang diperoleh siswa akan lebih bermakna daripada ditransfer secara langsung dari guru kepada siswa.

Hasil ini sesuai dengan pernyataan Nuhoglu dkk (2006:28-30) menyatakan bahwa penerapan model siklus belajar dapat meningkatkan prestasi belajar siswa dan mengurangi miskonsepsi pada materi listrik. Sornsakda dkk (2009:297) menyatakan bahwa pada umumnya siswa yang belajar menggunakan siklus belajar 7 fase dengan beberapa intelegensi mengalami 
peningkatan prestasi belajar, berfikir kritis secara keseluruhan dan dalam setiap aspek keterampilan proses terintegrasi secara keseluruhan dan dalam setiap aspek (kecuali dalam penentuan definisi tindakan) sebelum belajar. Polyiem (2011:259) menyatakan bahwa penerapan siklus belajar dapat meningkatkan keterampilan proses sains, prestasi belajar, dan budi pekerti siswa.

Proses pembelajaran bukan lagi sekedar transfer pengetahuan dari guru ke siswa, seperti dalam falsafah behaviorisme, tetapi merupakan proses pemerolehan konsep yang berorientasi pada keterlibatan siswa secara aktif dan langsung. Proses pembelajaran demikian akan lebih bermakna dan menjadikan skema dalam diri siswa menjadi pengetahuan fungsional yang setiap saat dapat diorganisasi oleh siswa untuk menyelesaikan masalah-masalah yang dihadapi.

\section{KESIMPULAN}

Berdasarkan analisis data dan pembahasan yang telah dilaksanakan pada penelitian ini maka dapat ditarik kesimpulan bahwa pembelajaran siklus belajar 7 fase dapat meningkatkan prestasi belajar siswa di kelas IXB SMPN 1 Pogalan, Trenggalek. Hal ini didasarkan pada peningkatan jumlah siswa yang tuntas belajar dari siklus I ke siklus II yaitu pada siklus I siswa yang tuntas belajar sebanyak 18 siswa (62\%) dan pada siklus II sebanyak 26 siswa (90\%). Ratarata nilai prestasi belajar kognitif siswa mengalami peningkatan $30 \%$ yaitu dari 70,5 pada siklus I dan siklus II sebesar 80,5.

Berdasarkan keputusan hasil penelitian, maka peneliti merekomendasikan beberapa hal sebagai berikut. (1). peningkatan prestasi belajar yang diamati dalam penelitian ini hanya mencakup ranah kognitif, sehingga diharapkan para peneliti lain yang ingin menggunakan model pembelajaran yang sama hendaknya juga meneliti aspek lain yaitu aspek afektif dan psikomotor pada prestasi belajar siswa. (2). kelemahan dari pelaksanaan pembelajaran dengan model siklus belajar 7 fase antara lain memerlukan waktu dan tenaga yang lebih banyak dalam menyusun rencana dan melaksanakan pembelajaran. Untuk itu disarankan kepada peneliti lain untuk menggunakan waktu seefektif dan seefisien mungkin agar waktu yang tersedia cukup untuk menyampaikan materi sesuai dengan target kurikulum.

\section{DAFTAR PUSTAKA}

Arikunto, Suharsimi. (2008). Dasar-dasar Evaluasi Pendidikan Edisi Revisi. Jakarta: Bumi Aksara

Bybee, R.W., Taylor, J.A, Gardner, A. Scotter, P.V, Powel, J.C, Westbrook, A \& Landes, N. (2006). The BSCS 7E Instruction Model: Origins, Effectiveness, and Application. Colorado Spring: Biological Sciencesa Curriculum Study. (Online), htpp://www.bscs.org/pdf/bscs7Eexeesummary.pdf). Diunduh 10 Oktober 2011

Dimyati \& Mudjiono. (1994). Belajar dan Pembelajaran. Jakarta: Dirjen Dikti Depdikbud.

Eisenkraft, A. (2003). Expanding The 5E Model. The Science Teacher. 70 (6), 56-59. (Online), htpp://www.its-about-time.com/htmls/ap/eisenkraftts/pdf diunduh 25 Nopember 2011.

Fajaroh \& Dasna. (2008). Pembelajaran dengan Model Siklus Belajar. (Online), htpp://sahaka.multiplay.com/jurnal/item/29/Pembelajaran Dengan Siklus Belajar Learning Cycle. Diunduh 25 Nopember 2011

Ibnu, S. (2008). Hand Out Mata Kuliah Dasar-dasar Pendidikan Sains. Tidak Diterbitkan. Malang: Universitas Negeri Malang.

Nurhadi, Yasin B., Senduk. A.G. (2004). Pembelajaran Konstektual dan Penerapannya dalam KBK. Malang: Universitas Negeri Malang

Nuhoglu H, dkk. (2006). The Effectivenes of Learning Cycle Model to Increase Student Achievment in the Physics Laboratory. Journal of Turkish Science Education, Vol. 2:3, pp. $28-30$.

Nuryani, R. (2005). Strategi Belajar Mengajar Biologi. Malang: UM Press. 
Polyiem, T., Nuangchalerm, P., Wongchantra, P. (2011). Learning Achievement, Science Process Skills, and Moral Reasoning of Ninth Grade Students Learned by $7 E$ Learning Cycle and Socioscientific Issue-based Learning. (Online) (http://www.insipub.com/ajbas/2011/October-2011/257-264.pdf - 33k. Diunduh 10 Oktober 2011).

Rustaman, N \& Andrian Rustaman. (1997). Pokok-pokok Pengajaran Biologi dan Kurikulum 1994. Jakarta: Departemen Pendidikan dan Kebudayaan. 